\title{
Application of Rooftop Rainwater Harvesting System in North East India
}

\author{
S.P. Sangeetha, P. S. Aravind Raj, Antony Sebastin, Vaishak S Nair, Hani Samad
}

\begin{abstract}
The main source of water, is rain for all life on earth. Rainwater harvesting is the best way to collect rainwater and utilize it effectively. Rainwater harvesting is used as a best method to collect and store water for future needs in water scarcity areas where water is not available throughout the year. This practice is becoming popular over the last few years as many people can no longer rely on the availability of ground water to satisfy their needs. North Eastern States in India experiences heavy rainfall in the country compared to other parts. Hence implementation of Rainwater Harvesting scheme in those regions will be a better choice to store water. A Case study on rainwater harvesting in sloped roof houses available in northeast India is done in this paper. Water scarcity problems can be minimised if rain water harvesting techniques are implemented in all households.
\end{abstract}

Key Words: Catchment area, harvesting, Rainwater, Runoff; storm water; scarcity.

\section{INTRODUCTION}

Due to the increase in population, there is a huge scarcity for water. To overcome this problem, collection and use of rainwater, will help us to conserve our ground water. For the preservation of all natural resources and for sustainable watershed development water is a key factor. Most of the Indian population use rain as major source of fresh water. The amount of rain water which recharges the aquifers is only $10-15 \%$, whereas remaining water flows into the water bodies or gets wasted. Hence to overcome the water scarcity and utilization of effective rain water rain water harvesting is followed as an effective technique. Rainwater can be stored either in an artificial storage or can be diverted to the soil media thereby recharging the groundwater.

Rain water harvesting is defined as the process of collecting and storing rain water to meet the future demand.

Revised Manuscript Received on January 30, 2020.

* Correspondence Author

S.P. Sangeetha*, Civil Engineering, Aarupadai Veedu Institute of Technology, VMRF, Paiyanoor, OMR, Chennai, Tamilnadu, India. Email: sangeetha@avit.ac.in

P. S. Aravind Raj, Civil Engineering, Aarupadai Veedu Institute of Technology,VMRF,Paiyanoor,OMR,Chennai,Tamilnadu,India. Email: aravindraj.civil@avit.ac.in

Vaishak S Nair, Civil Engineering, Aarupadai Veedu Institute of Technology,VMRF,Paiyanoor,OMR,Chennai,Tamilnadu,India. Email: vaishakcivil@avit.ac.in

Antony Sebastin, Civil Engineering, Aarupadai Veedu Institute of Technology, VMRF, Paiyanoor, OMR, Chennai, Tamilnadu, India

Hani Samad, Civil Engineering, Aarupadai Veedu Institute of Technology, VMRF, Paiyanoor, OMR, Chennai, Tamilnadu, India.

(C) The Authors. Published by Blue Eyes Intelligence Engineering and Sciences Publication (BEIESP). This is an open access article under the CC-BY-NC-ND license http://creativecommons.org/licenses/by-nc-nd/4.0/
The water can be collected in large tanks or containers which can be utilized when needed. In most of the cases, the water is then used directly even without purification. In places like Kerala, Mizoram, Tamil Nadu ,etc., where rain falls throughout the year, a small sized tank can be used for storing rainwater. Recharging is not possible wherever sub-strata is impermeable.

From the literatures reviewed, it was found that major portion of rainwater harvesting has its impacts on agricultural applications. Venkateshwara Rao (1996) in his article has reviewed the importance of artificial recharge of rainfall water for Hyderabad city water supply. Rainfall water from the roof tops of the buildings recharged through specially designed recharge pits in order to augment the ground water resource in the city. Ravikumar (2003) in his article has explained the roof top rainwater harvesting in Chennai Airport using GIS. Ghosh et al, (2009) have explainedin their paper about the various components in the roof top system of rain water harvesting in the North Eastern region. Rainwater harvesting in large storage structures is practiced in different parts of the India under different names such as Johads, Ahars, Talab, Munda, Tanka, etc.,

\section{ABOUT THE STUDY AREA - NORTHEAST INDIA}

The northeast hill region includes the states Assam, Nagaland, Manipur, Mizoram, Tripura, Arunachal Pradesh, Meghalaya, and Sikkim. The climate and rainfall area differ from place to place across the region. Total land area of the northeast region is 262,230 $\mathrm{km}$ sq(source: Wikipedia) and the total population is $45,772,188$. The northeast states comprises of Arunachal Pradesh, Assam, Mizoram, Manipur, Meghalaya, Nagaland, and Tripura. They are connected with railways, roadways or airways. Northeast region is mostly with hills and mountains terrains that rise in the northeast to Himalayas.

\section{Reasons for water scarcity}

1. Less knowledge and ideas to implement the use of slope roof rain water harvesting.

2. Dumping of waste in the rivers and streams.

3. Over use of groundwater. Due to more frequent extraction of groundwater than its recharge has affected the groundwater reserves and are vanishing rapidly

4. Increase in population.

5. We do not have a proper or efficient system for protecting water from contamination and also processes to treat groundwater at a lower cost.

Considering all these factors, the study has found out that many houses in northeast are made of sloped roof and also receives the highest rainfall when compared to other parts of India. But most of the people do not know the importance of sloped roof rain water harvesting.

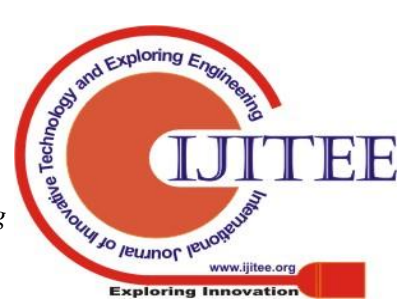




\section{Application of Rooftop Rainwater Harvesting System in North East India}

The increasing population has become a major problem in today's generation as usage of water is more but saving of water is less .It will be a great burden for the Middle and lower income people to buy water every day. Rainwater harvesting will definitely provide a solution for water scarcity. The average annual rainfall during the last five years in the areas chosen for study were collected and plotted as shown in figure1.

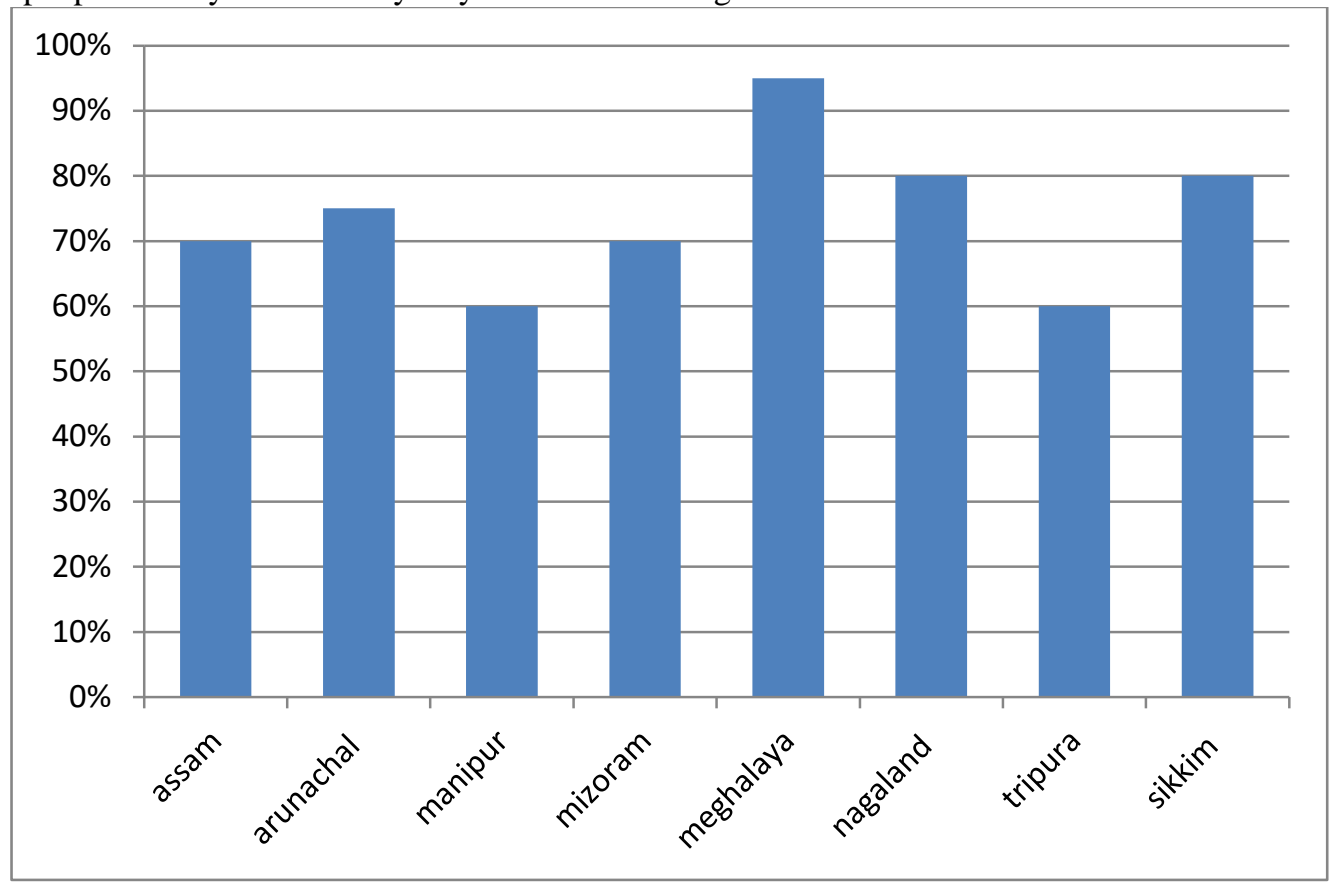

Figure 1 Annual rainfall in the areas chosen for study

The geographic, climatic, hydrological characteristics among states in north eastern regions overlap each other. Besides these, all these states are also similar to one another in terms of socio-economical situation. Major population of these regions depends on agricultural related activities. Though the annual rainfalls received in these states are relatively good, when compared to other parts of India, they suffer huge water scarcity. This is mainly due to insufficient water storage systems.

\section{ROOFTOP RAINWATER HARVESTING}

Rainwater can be harvested in several ways. Rooftop harvesting is method of harvesting rain water in which the rainwater is collected wherever it falls in built-up tanks, which can be utilised for direct consumption and also for recharging groundwater. Simple filtration devices connected to the system filters the collected water. In rooftop harvesting, the roof serves as the catchment basin and the rainwater is collected from the roof of the building. It can either be stored in a tank or diverted to artificial recharge system. This method is less expensive and very effective. If implemented properly, definitely it helps in augmenting the groundwater level of the area

A rooftop rainwater harvesting system consists of the following elements:

1. A Collection area

2. A Conveyance system

3. Water treatment system

4. Storage basin

5. Usage of water/Recharging techniques

The collection area in most of the cases is the roof of a house or a building. A conveyance system consists of gutters or pipes which collects rainwater falling on the rooftop to storage vessels. The water which gets collected through the rainwater harvesting system will be pure from impurities and does not require any special treatment. But if there are any pollutants from some external sources such as if a house has a chimney outlet at its the water may become smoky. In such a case high chimneys are to be provided if roof top harvesting system is practiced. To prevent from external pollutants, a proper lid should be provided. A first flush device has to be fitted to flush out the runoff from rain and does not allow water into the system. Usually larger amount of pollutants from the air and catchment area will be found in the first spell of rain which will be prevented by the flush device.

Both drainpipes and roof surfaces should be constructed with chemically inert materials such as wood, aluminum, plastic or fiberglass to avoid adverse effects on water quality. Storage tanks should be constructed with an inert material as part of the building or can also be built as separate units located some distance away from the building.Some roof surfaces are good for collecting rainwater and some are dangerous. Color bond steel sheets ,Glazed tiles well fired Zincalume steel sheets or tiles,, Concrete/cement tiles, Clay tiles, Fibro ,Composite tiles - bitumen based, etc., can be used as roofing materials for collecting potable water.

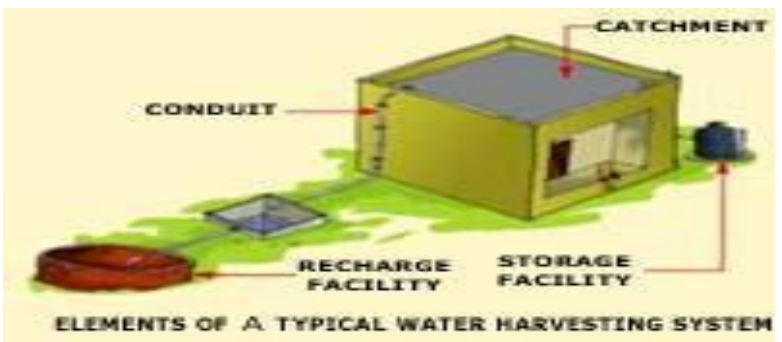

Figure 2: Components of a rain water harvesting system in roof top

Published By:

Blue Eyes Intelligence Engineering

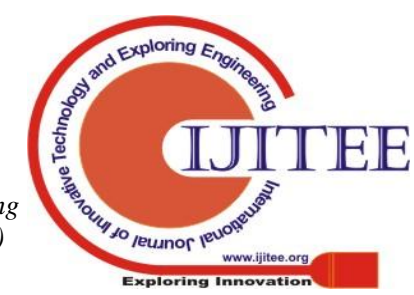


(Source: rainwaterharvesting.org)

This system of water harvesting system works efficiently only if it is maintained properly. It should be cleaned and checked at regular intervals .If any leakage found should be repaired immediately. Chlorination can be done to prevent form pollutants. To prevent clogging of gutters, debris and vegetation should be removed from gutters. Water quality should be checked if required.

\section{RESULTS AND DISCUSSIONS}

The rainwater harvesting structure proposed in this paper allows rainwater collected from roofs flows through the storm water pipes, which then flows into a storage tank for rainwater. If the storage capacity exceeds the limit, excess water will be diverted through a pipe which is connected to the sewage pipe. The construction depends on the functional requirement and the type of building, its catchment area, etc., For a residential house with an approximate built up area of 300- 400 sq.m, the approximate cost will be around Rs. 25,000-30,000. A recharge well should also be constructed near the borewell. Once constructed, the annual maintenance cost is very minimal in the range of $400-500$ for a labourer to clean and remove the pebbles and replace the sand from trenches. The rainwater harvested using this harvesting method may substitute only little quantity of water demand. But bigger the storage area larger will be the quantity of water stored.

\section{CONCLUSIONS}

Scarcity of water during summer in north eastern part of country is more common. As it cannot be solved with immediate effect, a concerted effort is needed to solve the problem. Rainwater harvesting system is an appropriate method to supplement the water demand. This paper attempts to focus on the sustainability and effectiveness of rainwater harvesting in sloped roofs. When harvesting rainwater in this way, the water that gets collected will be relatively pure and free from toxins and minerals. Over use of ground water may also results in depletion of groundwater. So people from northeast region should learn the methods for saving water through roof top rainwater harvesting. The main objective of this paper is to help and spread the knowledge and increase the use of slope roof rainwater harvesting in order to face crises and scarcity of water for future use.

\section{REFERENCES}

1. Goel AK, Kumar R (2005) Economic Analysis of water harvesting in mountainous watershed in India. Agricultural Water Management 71: 257-266.

2. Gnecco I, Berretta C, Lanza LG, La Barbera P (2006) Quality of storm water runoff from paved surfaces of two production sites. Water Sci Technology 54: 177-184.

3. Gould, J. and Nissen-Petersen, E. (1999), "Rainwater Catchment Systems for Domestic Supply”, Intermediate Technology Development Group (I.T.D.G.) Publication.

4. Haitbu N, Mutabazi K, Senkondo EM, Msangi ASK (2006) Economics of rainwater harvesting for crop enterprises in semi-arid areas of East Africa. Agricultural Water Management 80: 74-86.

5. V. Jothiprakash and Madnar V. Sathe (2009), "Evaluation of Rainwater Harvesting Methods and Structures Using Analytical Hierarchy Process for a Large Scale Industrial Area", JWRAP, VOL. No. VI, PP. 427 to 438.

6. Khastagir A, Jayasuriya N (2010) Optimal sizing of rain water tanks for domestic water conservation. Journal of Hydrology 381: 181-188.

7. Senkondo EMM, Msangi ASK, Xavery P, Lazaro EA, Hatibu N (2004) Profitability of Rainwater Harvesting for Agricultural Production in
Selected Semi-Arid Areas of Tanzania. J Applied Irrigation Science 39: 65-81. 17.

8. K. Venugopal and N. Ghosh (2010), "Rooftop Rainwater Harvesting at CWPRS, Pune; Maharastra - A Case Study", Journal of Applied Hydrology, ISSN 0971-670N, VOL. XXIII, No. 1 \& 2.

\section{AUTHORS PROFILE}

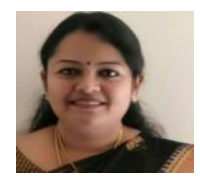

Dr. S.P.Sangeetha, Vice Principal (Academics) and Professor- Department of Civil Engineering has wide experience in Teaching and Designing. She is a active member in many Professional societies She has delivered invited lectures in various Institutions. She is the Programme Director for ISR. She has published several Journal papers in high indexed Journals

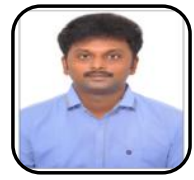

Dr.P.S.Aravind Raj M.E., Ph.D, has completed his doctorate in structural engineering in the year 2015 and has a total research experience of about 8 years. He is passionate on research in the fields of steel-concrete composites, sustainable materials, sustainable structures, etc. He has performed several research on beam-column connection of composite structures. He published and presented his research in many National as well as International conferences and also peer reviewed journals. Currently he is working as Associate Professor in the Department of Civil Engineering, AVIT. 